\title{
Pengaruh Perilaku Individu terhadap Semangat Kerja Karyawan pada Perusahaan Daerah Air Minum Tirta Bumi Wibawa Kota Sukabumi
}

\author{
Nur Fitri Indriani*, Faizal Mulia Z dan Kokom Komariah \\ Fakultas Ilmu Administrasi dan Humaniora, Program Studi Administrasi Bisnis \\ Universitas Muhammadiyah Sukabumi \\ "Email: nurfitri074@ummi.ac.id
}

\begin{abstract}
Abstrak
Tujuan dari penelitian ini adalah untuk mengetahui pengaruh perilaku individu terhadap semangat kerja karyawan di Perusahaan Daerah Air Minum (PDAM) Tirta Bumi Wibawa Kota Sukabumi. Metode yang digunakan dalam penelitian ini adalah metode kuantitatif dengan analisis regresi linear sederhana sebagai teknik analisis data dan menggunakan teknik sampling jenuh. Dengan jumlah reponden sebanyak 66 orang yaitu dengan survei pada Perusahaan Daerah Air Minum (PDAM) Tirta Bumi Wibawa Kota Sukabumi. Hasil penelitian yang menunjukkan bahwa perilaku individu berpengaruh terhadap semangat kerja karyawan. Total pengaruhnya sebesar 75,7\% Sedangkan sisanya sebesar 24,3\% dipengaruhi oleh variabel yang tidak diteliti dalam penelitian ini.
\end{abstract}

\section{Kata Kunci ; Perilaku Individu, Semangat Kerja}

\section{PENDAHULUAN}

Begitu pentingnya peran sumber daya manusia dalam menjalankan organisasi/ instansi/ perusahaan karena untuk memenuhi tujuan suatu perusahaan. Pada umumnya tujuan perusahaan adalah memperoleh laba yang maksimal, nama perusahaan dipandang baik serta kelangsungan hidup perusahaan. Oleh karena itu salah satu pencapaian tujuan tersebut memiliki karyawan yang berkualitas dan totalitas dalam bekerja, artinya karyawan dituntut untuk mempunyai kemampuan dalam bekerja. Managemen sumber daya manusia adalah bidang strategis dari organisasi. Sumber daya manusia harus dipandang sebagai perluasan dari pandangan tradisional untuk mengelola orang secara efektif dan untuk membutuhkan pengetahuan tentang perilaku manusia dan kemampuan mengelolanya (Eddy Sutrisno, 2016)

Selain itu juga menjalankan suatu usaha diperlukan adanya dorongan, semangat atau motivasi dari dalam diri seseorang sebagai bahan utama karyawan agar mampu bekerja dengan sungguh-sungguh, menyelesaikan tugas dengan baik dan menghasilkan produktivitas yang meningkat. Untuk itu salah satu faktor pendorong dari semangat kerja karyawan yaitu kenyamanan dalam perusahaan atau kantor dimana seseorang bekerja. Faktor penyebab munculnya semangat kerja yaitu adanya hubungan yang harmonis antara pimpinan dengan bawahan terutama antar pimpinan kerja sehari-hari yang lasnung berhubungan dan berhadapan dengan bawahan (Zainun, 2017). Maka dari itu dalam suatu perusahaan, atasan harus mampu menciptakan suasana atau kondisi dalam perusahaan agar terciptanya perilaku individu yang baik pada karyawan satu dan yang lainnya dalam perusahaan tersebut.

Sementara itu perilaku individu kadang dipandang sebelah mata oleh perusahaan, Karena tidak berpengaruh terhadap hasil pekerjaan. Padahal semangat kerja seseorang dilihat dari dalam diri karyawan memiliki rasa nyaman atau tidak dalam menyikapi pekerjaan mereka. Perilaku individu merupakan interaksi karyawan dengan lingkungannya atau dengan karyawan yang lain dan memiliki karakteristik yang berbeda. Begitu pentingnya bagi atasan memperhatikan perilaku individu setiap karyawan nya. Selain atasan karyawan juga dituntut untuk menciptakan suasana pekerjaan yang nyaman dan komunikasi yang baik dengan karyawan yang lainnya agar mampu merasakan kenyamanan dan membangkitkan semangat kerja karyawan.

Objek penelitian dalam penelitian penulis ini adalah PDAM (Perusahaan Daerah Air Minum) Tirta Bumi Wibawa Kota Sukabumi yang berdiri berdasarkan peraturan Daerah Tingkat II Kota Madya pada tanggal 20 Agustus 1975 dan berlokasi di Jl. Bhayangkara No. 207, Selabatu, Kecamatan Cikole, Kota Sukabumi. Adalah Perusahaan Daerah yang bergerak dibidang air bersih yang sesuai dengan nilai dan syarat kesehatan. Lalu perusahaan ini memliki tujuan melayani 
kepentingan masyarakat yaitu dengan menyalurkan air bersih ke rumah warga, tempat usaha, kantor, dan fasilitas umum yang dibutuhkan untuk kegiatas sehari-hari.

Permasalahan yang ada pada PDAM Tirta Bumi Wibawa Kota Sukabumi ini adalah sering terciptanya keadaan kantor yang kurang baik dikarenakan perilaku individu yang kurang nyaman terhadap karyawan satu dengan yang lainnya, dikarenakan karyawan kurang mampu menciptakan rasa kenyamanan dan kurangnya komunikasi yang baik dengan atasan. Oleh karena itu diawali dari atasan yang harus mampu mempedulikan keadaan suatu perusahaan, agar bisa menumbuhkan rasa semangat kerja yang tinggi kepada karyawannya.

\section{KAJIAN PUSTAKA}

Menurut Thoha 2000 dalam (Pertanahan and Tabalong n.d.) Perilaku individu adalah sebagai suatu fungsi dari interaksi antara seseorang atau individu dengan lingkungan. Berarti perilaku individu merupakan tingkah laku seseorang terhadap lingkungannya dan memiliki karakter yang sangat berbeda.

Sedangkan menurut Gibson 2007 dalam (Tanasal, Kojo, and M.Sendow 2016) Perilaku merupakan semua tindakan yang dilakukan individu atau tindakan yang menunjukkan tingkah seseorang dan tindakan-tindakan tersebut dapat diamati, oleh sebab itu perilaku seseorang yang bertingkah laku baik atau buruk akan mempengaruhi individu yang lainnya karena tingkah laku mereka dapat diperhatikan oleh sesama karyawan dalam ruang yang sama. Dapat diartikan tingkah laku seseorang yang baik akan mempengaruhi semangat kerja karyawan yang lainnya.

Dalam penelitian (Tanasal, Kojo, dan M. Sendow 2016) yang dikemukakan oleh (Kuspriatni, 2015) Perilaku Individu terdapat beberapa dimensi yaitu :

1. Karaskteristik biografis : usia, jenis kelamin, masa kerja

2. Kemampuan tersendiri atas pekerjaan

3. Kepribadian seseorang

4. Emosi

5. Pembelajaran

Sudah layaknya setiap instansi atau perusahaan memberikan dorongan atau motivasi kepada karyawannya, agar semangat karyawan meningkat. Dengan semangat yang tinggi maka dengan otomatis tujuan perusahaan akan dengan mudah dicapai.

Menurut Nitisemito 2001 dalam (Made and Kansa 2019) semanngat kerja ialah melaksanakan pekerjaan lebih giat sehingga dengan demikian pekerjaan akan selesai lebih cepat dan baik.

Sedangkan menurut Siswanto 2001 dalam (Made and Kansa 2019) semangat kerja merupakan suatu kondisi rohaniah tenaga kerja dan kelompok-kelompok yang menimbulkan kesenangan dari dalam diri pekerja untuk bekerja dengan giat dan konsentrasi dalam mencapai tujuan, aturan, dan niat yang di tetapkan oleh perusahaan.

Semangat kerja adalah sikap mental seorang individu atau kelompok yang menunjukkan gairah agar melaksanakan tugas pekerjaanya dan mendorong untuk mampu bekerjasama dan dapat menyelesaikan pekerjaan dengan tepat pada waktunya serta memiliki rasa tanggung jawab terhadap pekerjaan yang dibebankan kepadanya (Edwandar 2017). Dengan adanya dorongan motivasi kepada karyawan maka karyawan akan memiliki rasa tanggung jawab terhadap beban kerja.

Menurut Tohardi 2002 dalam (Ni Made Diah Malini Cahyani 2019) semangat kerja dan moral kerja adalah sikap-sikap dari individu maupun kelompok terhadap lingkungan pekerjaan. Dan terhadap kesiapan untuk bekerja sama agar dapat menyesuaikan kemampuannya dengan kebutuhan pekerjaan. Selain pemberian motivasi atau dorangan juga, semangat kerja dapat ditingkatkan dengan cara mengurangi kesalahan yang pernah dilakukan karyawan dalam menyelesaikan pekerjaanya.

Berdasarkan pengertian para ahli diatas dapat dinyatakan bahwa perilaku inividu atau kelompok yang kurang baik atau kurang menumbuhkan rasa kenyamanan maka akan mempengaruhi semangat kerja pada karyawan, dan menghambat terhadap pekerjaan yang dibebankan kepada masing-masing karyawan.

Dalam Penelitian (Bayu Arifandi, 2015) ada beberapa dimensi semangat kerja yaitu :

1. Tingkat Produktivitas 
2. Tingkat kehadiran

3. Tingkat perpindahan

4. Tingkat kegelisahan

\section{METODE PENELITIAN}

Metode penelitian ini tujuannya untuk menganalisis pengaruh perilaku individu terhadap semangat kerja karyawan. Survei pada PDAM Tirta Bumi Wibawa Kota Sukabumi. Penelitian ini menggunakan metode deskriptif asosiatif dengan menggunakan pendekatan kuantitatif. Metode deskriptif adalah metode penelitian yangdilakukan untuk mengetahui nilai variabel mendiri, baik satu variabel atu lebih tanpa membuat perbandingan atau menghubungkan dengan variabel yang lain. Sedangkan metode penelitian asosiatif adalah metode penelitian yang bertujuan untuk mengetahui hubungan antara dua variabel atau lebih (Sugiyono 2017).

\section{HASIL DAN PEMBAHASAN}

Perusahaan memiliki masalah yang berkenaan dengan dengan semangat kerja karyawannya. Salah saru yang mempengaruhinya yaitu perilaku individu yang ada pada diri karyawan yang memiliki rasa kurang nyaman serta karyawan kurang mampu mempertanggungjawabkan pekerjaan yang dibebani oleh perusahaan. Sebagaimana data hasil kuesioner (Tabel 1) yang menunjukkan bahwa penelitian ini dilakukan dengan terstandar, sehingga dengan cara umum memberikan informasi bahwa perilaku individu sangat berpengaru terhadap semangat kerja karyawan di PDAM Tirta Bumi Wibawa Kota Sukabumi. berikut :

Adapun hasil yang diperoleh peneliti setelah melakukan penyebaran kuesioner yaitu sebagai

Tabel 1. Hasil Uji Validitas X dan Y

\begin{tabular}{|l|l|l|l|l|}
\hline Variabel & $\mathrm{R}_{\text {hitung }}$ & $\mathrm{R}_{\text {tabel }}$ & Sig. & Hasil \\
\hline Y.1 & 0.801 & 0.238 & .000 & Valid \\
\hline Y.2 & 0.864 & 0.238 & .000 & Valid \\
\hline Y.3 & 0.831 & 0.238 & .000 & Valid \\
\hline Y.4 & 0.887 & 0.238 & .000 & Valid \\
\hline X1.1 & 0.833 & 0.238 & .000 & Valid \\
\hline X1.2 & 0.899 & 0.238 & .000 & Valid \\
\hline X1.3 & 0.896 & 0.238 & .000 & Valid \\
\hline X1.4 & 0.810 & 0.238 & .000 & Valid \\
\hline X1.5 & 0.799 & 0.238 & .000 & Valid \\
\hline X1.6 & 0.829 & 0.238 & .000 & Valid \\
\hline X1.7 & 0.865 & 0.238 & .000 & Valid \\
\hline
\end{tabular}

Sumber : Peneliti,2020

Tabel 2. Hasil Uji Reliabilitas Y dan X Reliabilitas X dan Y

\begin{tabular}{|l|l|l|c|}
\hline \multicolumn{2}{|c|}{ Reliability Statistic Y } & \multicolumn{2}{c|}{ Reliability Statistic X } \\
\hline $\begin{array}{l}\text { Cronbach's } \\
\text { Alpha }\end{array}$ & $\begin{array}{l}\text { Items } \\
\text { Itef }\end{array}$ & $\begin{array}{l}\text { Cronbach's } \\
\text { Alpha }\end{array}$ & $\begin{array}{c}\text { N of } \\
\text { Items }\end{array}$ \\
\hline $\mathbf{0 . 8 2 8}$ & 4 & 0.800 & 7 \\
\hline
\end{tabular}

Sumber : Diolah Peneliti, 2020

Hasil dari uji reliabilitas Perilaku Individu adalah $80.0 \%$, kuesioner variabel $\mathrm{X}$ dapat di anggap reliable karena nilai dari hasil data di atas menunjukkan $80.0 \%$ lebih besar dari $60 \%$. Dan uji reliabilitas $\mathrm{Y}$ adalah $82.8 \%$ dapat diamggap reliable karena nilai $82.8 \%$ lebih besar dari $60 \%$. 
Tabel 3. Analisis Regresi Linear Sederhana

\begin{tabular}{|l|l|l|}
\hline \multirow{2}{*}{ Model } & \multicolumn{3}{|l|}{$\begin{array}{l}\text { Understandized } \\
\text { Coefficient }\end{array}$} \\
\cline { 2 - 3 } & $\mathbf{B}$ & Std. Error \\
\hline (constant) & $\mathbf{0 . 8 2 5}$ & $\mathbf{0 . 9 5 4}$ \\
\hline Perilaku Individu & $\mathbf{0 . 5 2 5}$ & $\mathbf{0 . 0 3 7}$ \\
\hline
\end{tabular}

Sumber : Diolah Peneliti, 2020

Tabel diatas menjelaskan bahwa nilai konstanta sebesar 0.825 sedangkan nilai variabel Perilaku Individu $(X)$ sebesar 0.525 sehingga persamaan ditulis sebagai berikut :

$\mathrm{Y}=\mathrm{a}+\mathrm{b} \mathrm{X}$

$\mathrm{Y}=0.825+0.525 \mathrm{X}$

1. Persamaan diatas menjelaskan bahwa nilai konstanta sebesar 0.825 yang berarti nilai konsisten variabel Y sebesar 0.825

2. Koefisien regresi $X$ sebesar 0.525 menyatakan bahwa setiap penambahan $1 \%$ nilai X. Maka, partisipasi bertambah sebesar 0.525 koefisien regresi bernilai positif. Dikatakan bahwa perilaku individu berpengaruh positif terhadap semangat kerja karyawan.

Tabel 4. Tabel Koefisien Korelasi

\begin{tabular}{|l|l|l|}
\hline Model & $\mathbf{R}$ & R Square \\
\hline 1 & $\mathbf{0 . 8 7 0}$ & 0.757 \\
\hline
\end{tabular}

Sumber : Diolah Peneliti, 2020

Berdasarkan tabel diatas menjelaskan bahwa besarnya nilai korelasi (R) yang tinggi yaitu sebesar 0.870 dan diperoleh Koefisien Determinasi ( $R$ Squre) sebesar 0.757 yang berarti bahwa pengaruh variabel Perilaku Individu terhadap semangat kerja karyawan adalah sebesar 75,7\%

Tabel 5. Hasil Uji F

\begin{tabular}{|l|l|}
\hline F & Sig. \\
\hline 199.475 & .000 \\
\hline
\end{tabular}

Sumber : Diolah Peneliti, 2020

Tabel diatas menjelaskan bahwa nilai $\mathrm{F}$ hitung 199.475 sedangkan $\mathrm{F}$ Tabel 3.99 dan nilai regresi memiliki tingkat signifikan $0.000<0.05$, maka $199.475>3.99$ disimpulkan bahwa adanya pengaruh signifikan antara variabel perilaku individu terhadap semangat kerja karyawan.

Tabel 6. Hasil Uji T

\begin{tabular}{|c|c|c|}
\hline Model & T & Sig. \\
\hline (Constant) & $\mathbf{0 . 8 6 5}$ & $\mathbf{0 . 3 9 0}$ \\
\hline Perilaku Individu & $\mathbf{1 4 . 1 2 4}$ & $\mathbf{0 . 0 0 0}$ \\
\hline
\end{tabular}

Sumber : Diolah Peneliti, 2020

Tabel diatas menjelaskan bahwa nilai signifikan sebesar $0.000<0.05 \mathrm{~T}$ hitung sebesar 14.124 $>\mathrm{T}$ tabel 1.66 ,maka dapat ditarik kesimpulan adanya pengaruh signifikan antara perilaku individu terhadap semangat kerja karyawan. 


\section{KESIMPULAN}

Penelitian ini bertujuan untuk menganalisis pengaruh perilaku individu terhadap semangat kerja karyawan. Harapannya dapat memajukan perusahaan dengan cara menuntut karyawan untuk berperilaku baik agar meningkatkan semangat kerja karyawan. Dari analisi yang telah dilakukan, maka dapat disimpulkan bahwa hipotesis menunjukkan perilaku individu berpengaruh terhadap semangat kerja karyawan. Dalam arti semakin baik perilaku individu yang dilakukan oleh karyawan, maka semangat kerja karyawan akan lebih baik.

\section{DAFTAR PUSTAKA}

Eddy Sutrisno, . 2016. Manajemen Sumber Daya Manusia. Jakarta: Kencana

Edwandar, Bonni. 2017. Pengaruh Lingkungan Kerja Terhadap Semangat Kerja Karyawan Pada Cv. Jaya Pekanbaru." 4(1): 1-15.

Made, Ni, and Dewi Kansa. 2019. Ni Made Dewi Kansa Putri Peran Semangat Kerja. 1(2): 60-76.

Irham Fahmi,S.E., M.Si. 2013. Manajemen Kinerja. Bandung: ALFABETA

Sugiyono. 2017. Metode Penelitian. Bandung: ALFABETA,CV.

Pertanahan, Kantor, and Kabupaten Tabalong. "Web : Http://Jurnal.Stiatabalong.Ac.Id Pengaruh Budaya Organisasi Terhadap Perilaku Individu Pada Kantor Pertanahan Kabupaten Tabalong Yuzan Noor *." 2(2): 196-207.

Tanasal, Rivaldy, Christoffel Kojo, and Greis M.Sendow. 2016. Analisis Beban Kerja, Perilaku Individu Dan Persepsi Terhadap Kinerja Karyawan PT Hasjrat Abadi Manado. Emba 4(5): 456-66. 